\title{
Modelling and Simulation Applied to Gluten-Free Craft Beer: Case Study of a Manufacturing Process
}

Junio Henrique Almeida Beatriz ${ }^{1}$, Juliana Cristina Honorato ${ }^{2}$, Emanuelle Mayara da Cunha ${ }^{3}$, Flávio Ramon Silva de Souza ${ }^{4}$, Giovana Gomes da Silva Beliene Vila ${ }^{5}$, Isabella de Oliveira Pereira ${ }^{6}$, Isadora Rodrigues de Oliveira ${ }^{7}$, Mariana Alves dos Anjos ${ }^{8}$, Núbia Cristina Fraga de Carvalho Gomes ${ }^{9}$, Mário Victor dos Reis ${ }^{10}$, Luiz Melk de Carvalho ${ }^{11}$, Flávio Henrique Batista de Souza ${ }^{12 *}$

Centro Universitário de Belo Horizonte - UNIBH, Brazil

flabasouza@yahoo.com.br

\begin{abstract}
Beer is one of the most consumed products on the planet (even in the pandemic scenario by COVID-19). The manufacture of craft beers corresponds to an interesting sector for the economy of any country. However, this does not exempt anyone from going through complicated situations, such as what happened at the Backer brewery and its product contamination process. So, this paper aims to demonstrate the implementation of a discrete event modeling and simulation process, based on stochastic timed petri nets (STPN) for a gluten-free craft beer manufacturing process. The developed tool was submitted to uniform and exponential distribution functions. Its operation was weighted by a real manufacturing process for the specific type of beer evaluated. The simulator demonstrated the ability to abstract all the stages of product manufacture. In addition, the tool was able to understand both distribution functions that the manufacturing process can assume, through a literature tool, STPN. This process can be applicable in small entrepreneurs., which sometimes cannot afford (or do not understand how it works) simulation software.
\end{abstract}

Keywords: craft beer, stochastic timed petri nets, modelling and simulation, gluten-free, small business 


\section{$3^{\text {rd }}$ International Conference on Research in SCIENCE, ENGINEERING AND TECHNOLOGY}

11-13 March, 2021

Oxford - United Kingdom

\section{Introduction}

With the use of modeling and simulation, it is possible to provide micro and small entrepreneurs with the ability to develop a planned management of handmade products. The micro and small companies, according to the Brazilian Micro and Small Business Support Service - SEBRAE (2018), have an important participation in the Brazilian economic scenario. They represent about $99 \%$ of the total establishments in the national territory. According to data from the Brazilian Association of the Beer Industry - CERVBRASIL (2016), Brazil is the third largest producer of beer in the world, and represents almost $2 \%$ of the Gross Domestic Product - Brazilian GDP.

Included in this statistic, craft beer is made with a focus on quality, and its production process is planned with the aim of bringing a differentiated identity to beer (Ferreira et al. 2011). However, within the consuming public there are people who are intolerant to gluten or who decide for a dietary reason not to ingest this protein, and are looking for alternative foods, which among these foods includes gluten-free beer (Arendt \& Dal Bello, 2011).

To assist in the management of small and micro companies, including those in the beer industry, there are organizational tools to control and optimize their processes, which according to Walter \& Meluch (2019), are methods adopted in corporate environments that aim to adapt or implement measures that generate improvements within organizations. In the case of brewing companies, even though it is an artisanal process, the organizational tools enable the standardization of processes, producing knowledge in an organized manner.

Through a standardized process, it is possible to use process modeling and simulation tools, such as the Petri Net, which according to Lisboa et al. (2019) is based on a "mathematical model with graphical representation". Still according to the author, it is a model widely used to solve several problems in different sectors, among them: production, logistics, communication and information processes.

The relevance of this research is based on the growth of the beer market, mainly the market of micro and small companies, which is expanding. According to the Brazilian Craft Beer Association - ABRACERVA (2019), from 2017 to 2018 there was a 23\% growth in the number of craft beers and expansion of the consuming public. However, there is a great risk related to the growth of this market due to the excessive consumption of beer, which can generate losses to society, leading the government to create means to intervene in growth, for example, increase in taxes on the product. On the other hand, growth can be hindered by micro and small entrepreneurs themselves, through the lack of standardization of processes within the industrial environment. An aggravating factor: in addition to the COVID-19 pandemic that significantly affected the world economy, scandals regarding artisanal producers shook the beer market (Stocker \& Abib, 2019).

The general objective of this article is to develop a methodology based on modeling and simulation for production service scenarios, that is, optimization of the productivity of glutenfree beer of a small producer. The specific objectives are: to know the process of a gluten-free beer; present a standardized flowchart of resources, time and production activities of the process; and, to develop a model through the modeling and simulation tool with the Petri Net, which will provide the possibility of expansion or retraction, according to market scenarios for 


\section{$3^{\text {rd }}$ International Conference on Research in SCIENCE, ENGINEERING AND TECHNOLOGY}

11-13 March, 2021

\section{Oxford - United Kingdom}

the type of company. As gaps in this project, the behavior of materials, inventory management needs, and places to commercialize are not known, since the company has not yet been included on the market, leaving uncertainty about the acceptance of the proposed product.

Thus, the following questions were established that guide the execution of this research: what would a standardized flowchart look like in the already artisanal process? how would modeling and simulation based on Petri Nets be? what would management based on Petri Nets look like? These questions are answered throughout this study. Mainly, in the results and discussions where the possible solutions to these gaps will be presented.

\section{Material and Methods}

\subsection{Stochastic Timed Petri Nets}

The Petri Net are composed of transitions $(T)$, arcs $(A)$ and places $(P)$. A transition is an active element in the Petri Net, represented by a bar or rectangle. Places or positions are passive elements represented by a circle, interpreted as a condition, resources, information or procedures. They are associated with events that occur in the system.

The nodes of a Petri Net are connected by arcs, labelled with weights (positive integers). Stochastic Timed Petri Nets (STPN), on the other hand, associate a stochastic distribution for firing times (Lisboa et al., 2019). Figure 1 shows an example of an STPN.

Source: Lisboa et. Al, 2019.

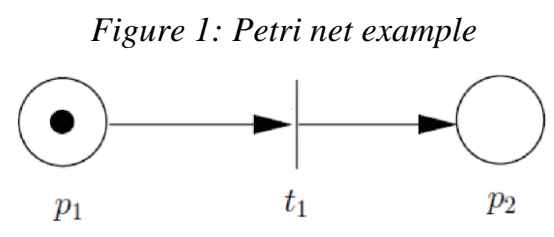

\subsection{Methods}

Within the process of scientific methodology, this work was guided by research and evaluation methods. Quantitative research methodologies were addressed, due to the study of the correlation of variables and comparative causal studies, presented as modeling and simulation of scenarios about the theme. A qualitative research was also developed, due to the descriptive studies, necessary to understand the case in analysis, based on the knowledge of the researchers Through this methodology the flowchart of the gluten-free craft beer production process was developed.

In addition to these and according to the study of the flowchart of the production process of the aforementioned product and the modeling and simulation of production scenarios, solutions were proposed according to the results achieved. For the development of this research, during the experimentation process, data were first collected and the production process of gluten-free craft beer was studied.

Once the process was understood, standardization was developed through a flowchart, in order to determine the sequence of activities and amount of resources and time spent in the process. Therefore, a modeling and simulation was carried out through the Petri net, using the 


\section{$3^{\text {rd }}$ International Conference on Research in SCIENCE, ENGINEERING AND TECHNOLOGY}

times and resources to model scenarios, the results of which were carried out in order to propose the expansion of the small and micro craft beer manufacturer.

\section{Results}

\subsection{Productive Flowchart}

The flowchart of the aforementioned process, which can be seen in Figure 2, was developed to provide the standardization of the process in the management of the business of the micro and small beer producer. In order for the producer to be in control of the process and to be able to visualize possible bottlenecks that may arise, taking an immediate action plan to resolve the verified failure. Before talking about the technological sequence of production of gluten-free craft beer, it is important to present the necessary resources for production, that is, the raw materials used in the process. The essential resources needed for production are: water, malt, hops, yeasts and enzymes. Water is the main resource used in the process, as it represents more than $90 \%$ of the product. Malt is the resource responsible for providing nutrients and sugars that will act as food for yeasts. In the fermentation process, alcohol and carbon dioxide are produced.

In addition, the type of malt, as well as its intensity, are both decisive for beer characteristics such as: color, flavor and aroma. Hops, in addition to being a natural preservative, provide the flavor and aroma to the beer, and are also responsible for bitterness. Yeasts are fungi, that is, single-celled microorganisms that reproduce by sprouting. They are responsible for fermentation and the best known, namely: Saccharomycescerevisiae and Saccharomycesuvarum, grant the styles beers, which can be Ale or Larger. And finally, enzymes that are biocatalysts, accelerate chemical reactions in the production process, although they do not participate in such reactions. These enzymes can increase the rate of catalyzed reactions by 106 to 1012 times.

Figure 2: Flowchart of the gluten-free craft beer production process

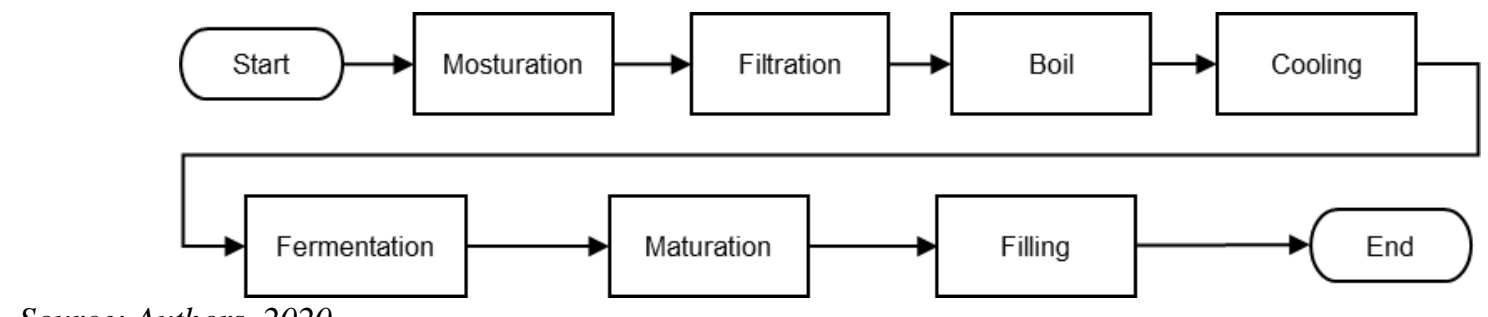

Source: Authors, 2020.

Once the raw materials used in the production process are presented, the following are the technological sequence based on the process flowchart, shown in figure 2 . The process begins by filtering the water in order to make it pure for its use in the beer manufacturing process. The purpose of filtration is to remove chlorine and minerals from the water. This procedure is carried out by means of a three-stage filter, after which a water purification test is performed.

Thus, in the first stage of the manufacturing, the mashing process is carried out, where 12 $\mathrm{kg}$ of malt is added in a container with 60 liters of filtered water. This mixture is heated in three stages of heating. In the first stage the wort is heated to $68{ }^{\circ} \mathrm{C}$ for 60 minutes, in the second 
stage to $71{ }^{\circ} \mathrm{C}$ for 70 minutes and in the third to $78{ }^{\circ} \mathrm{C}$ for 10 minutes. After this process is completed, the mixture is left to stand for 10 minutes. This step is also responsible for hydrating the malt and activating the enzymes, resulting in the conversion of starch into fermentable sugars and proteins into nutrients. For the specific purposes of this project, there is no malt milling process, since the malt is already ground in a specific establishment.

After mashing, the filtration process begin, where the malt bagasse is separated from the wort, which lasts about 40 minutes. This process is carried out using a common sieve. Then, the boiling occurs, which is a process where the wort is brought to a boil for a period of 70 minutes and concomitantly the hops are added to the mixture. Thus, in this stage, the enzymes are deactivated, the wort is sterilized and the characteristic bitterness of the beer is produced.

After boiling, the wort is cooled using a serpentine whose final temperature is $9{ }^{\circ} \mathrm{C}$ (this process is carried out in 57 minutes). Then, the fermentation stage is opened to receive the addition of yeast and the enzyme that breaks down gluten proteins and it is packed in a gallon and, then, in a refrigerator where it remains for 5 days at a temperature of $9{ }^{\circ} \mathrm{C}$. After that, the temperature is adjusted to $18{ }^{\circ} \mathrm{C}$ and the wort remains for another 5 days at that temperature. The second filtration of the process takes place after the fermentation step. At this step the filtration is done again in order to remove the yeast that decanted at the bottom of the container used in the previous step (this process is carried out in 60 minutes). Then, the maturation phase begin, where the wort is kept at a controlled temperature of $18{ }^{\circ} \mathrm{C}$ for a period of 10 days.

The manufacturing process of gluten-free craft beer ends with the filling process. In this stage, the beer is filled in $600 \mathrm{ml}$ bottles and kept in a dark place at room temperature for 7 days. It is important to note that during the entire brewing process there is an iodine test in fractions of the must in order to verify the percentage of starch in the composition. After analyzing the flowchart and presenting each step, it is possible to collect data on the processes, resources and times of each stage of the manufacturing process, as shown in table 1 .

Table 1: Processes, resources and times of the gluten-free craft beer production process

\begin{tabular}{|c|c|c|c|}
\hline Process & Sub process & Resources & Time (min) \\
\hline \multirow{4}{*}{ Mosturation } & Wort Heating $1-68^{\circ} \mathrm{C}$ & Malt, water and activated enzymes & 60 \\
\hline & Wort Heating $2-71^{\circ} \mathrm{C}$ & Malt, water and activated enzymes & 70 \\
\hline & Wort Heating $3-78^{\circ} \mathrm{C}$ & Malt, water and activated enzymes & 10 \\
\hline & Rest & Wort & 10 \\
\hline Filtration & Separation of malt bagasse from must & Wort & 40 \\
\hline \multirow{4}{*}{ Boil } & Must boil & \multirow{4}{*}{ Wort, hops and enzymes } & \multirow{4}{*}{70} \\
\hline & Hop addition & & \\
\hline & Sterilization of wort & & \\
\hline & Inactivation of enzymes & & \\
\hline Cooling & Cooling down to $9^{\circ} \mathrm{C}$ & Wort & 57 \\
\hline \multirow{2}{*}{ Fermentation } & $\begin{array}{l}\text { Controlled temperature fermentation } \\
\qquad\left(9^{\circ} \mathrm{C}\right)\end{array}$ & \multirow{2}{*}{ Wort } & 7.200 (5 days) \\
\hline & $\begin{array}{l}\text { Controlled temperature fermentation } \\
\qquad\left(18^{\circ} \mathrm{C}\right)\end{array}$ & & 7.200 (5 days) \\
\hline Filtration & Yeast removal & Wort & 60 \\
\hline Maturation & Controlled temperature $\left(18^{\circ} \mathrm{C}\right)$ & Wort & $\begin{array}{c}14.400(10 \\
\text { days })\end{array}$ \\
\hline \multirow{2}{*}{ Filling } & Filling in $600 \mathrm{ml}$ bottles & \multirow{2}{*}{ Beer } & \multirow{2}{*}{$\begin{array}{c}10.080(7 \\
\text { days })\end{array}$} \\
\hline & Dark storage and room temperature & & \\
\hline
\end{tabular}




\section{$3^{\text {rd }}$ International Conference on Research in SCIENCE, ENGINEERING AND TECHNOLOGY}

11-13 March, 2021

Oxford - United Kingdom

In view of the data presented in table 1, referring to the production process of gluten-free craft beer, which resulted in the production of 55 liters, and was hypothetically named as process 1 for the purpose of understanding the manufacturing process, it was possible to analyze the total process time of 39,257 minutes (27.26 days). The total time in days was 27.26, which corresponds to 27 days, 6 hours and 17 minutes as the total time for production referring to the manufacturing process 1 . For a large gluten-free craft beer production scale, table 1 received some processes that were not used, as they were outsourced. If the manufacturer wishes to take over all the manufacturing processes, it is necessary to stick to the times and activities of the complete process. The data added in this result were raised based on the literature and resulted in table 2 .

The added processes were: malting, grinding, clarification and pasteurization. The malting process is divided into three sub processes: maceration, germination and drying. In maceration the seeds are submitted to the degree of humidity necessary for germination. In germination, enzymes are developed and the starch is modified, making it soft and soluble. Drying is the process where biological activity stops, that is, at the point where the production of enzymes and changes in starch reach the optimum level. In grinding the malt grain is crushed by rolls, which can be two, four or six, in addition to tapered rolls. In clarification, the necessary sugars are extracted and the wort becomes clearer. Pasteurization is a heat treatment that the beer undergoes in order to increase the durability of the beer. Figure 3 shows the flowchart resulting from the addition of the aforementioned data. As before, the process shown in table 2 received the hypothetical designation of manufacturing process 2 . The total time of artisanal beer production with the addition of new data for large-scale production was 53,658 minutes (37.26 days). The total time in days was 37.26, which corresponds to 37 days, 6 hours and 17 minutes as the total time for production referring to the manufacturing process 2 . Such data is used as parameters for defining scenarios modeling and simulation using Petri nets, discussed in the next items of this article. 
Table 2: Processes, resources and times of the gluten-free craft beer production process for large-scale production

\begin{tabular}{|c|c|c|c|}
\hline Process & Sub process & Resources & Time $(\mathrm{min})$ \\
\hline \multirow{3}{*}{ Malting } & Maceration & Barley & 3.600 (2,5 days) \\
\hline & Germination & Barley & 8.640 (6 days) \\
\hline & Drying & Barley & 2.160 (1,5days) \\
\hline Milling & $\mathrm{xx}$ & Malt & 1 \\
\hline \multirow{4}{*}{$\begin{array}{l}\text { Mosturation } \\
\text { and } \\
\text { Clarification }\end{array}$} & Wort Heating $1-68^{\circ} \mathrm{C}$ & $\begin{array}{l}\text { Malt, water and } \\
\text { enzymes activated }\end{array}$ & 60 \\
\hline & Wort Heating $2-71^{\circ} \mathrm{C}$ & $\begin{array}{l}\text { Malt, water and } \\
\text { enzymes activated }\end{array}$ & 70 \\
\hline & Wort Heating $3-78^{\circ} \mathrm{C}$ & $\begin{array}{l}\text { Malt, water and } \\
\text { enzymes activated }\end{array}$ & 10 \\
\hline & Rest & Wort & 10 \\
\hline Filtration & Separation of malt bagasse from must & Wort & 40 \\
\hline \multirow{4}{*}{ Boil } & Must boil & \multirow{4}{*}{$\begin{array}{l}\text { Wort, hops and } \\
\text { enzymes }\end{array}$} & \multirow{4}{*}{70} \\
\hline & Hop addition & & \\
\hline & Sterilization of wort & & \\
\hline & Inactivation of enzymes & & \\
\hline Cooling & Cooling down to $9^{\circ} \mathrm{C}$ & Wort & 57 \\
\hline \multirow{2}{*}{ Fermentation } & Controlled temperature fermentation $\left(9^{\circ} \mathrm{C}\right)$ & \multirow{2}{*}{ Wort } & 7.200 (5 days) \\
\hline & Controlled temperature fermentation $\left(18^{\circ} \mathrm{C}\right)$ & & 7.200 (5 days) \\
\hline Filtration & Yeast removal & Wort & 60 \\
\hline Maturation & Controlled temperature $\left(18^{\circ} \mathrm{C}\right)$ & Wort & 14.400 (10 days) \\
\hline \multirow{3}{*}{$\begin{array}{c}\text { Filling and } \\
\text { Pasteurization }\end{array}$} & Filling in $600 \mathrm{ml}$ bottles & \multirow{3}{*}{ Beer } & \multirow{3}{*}{10.080 (7 days) } \\
\hline & Pasteurization & & \\
\hline & Dark storage and room temperature & & \\
\hline
\end{tabular}

Source: Authors, 2020.

Figure 3: Flow chart of the gluten-free craft beer production process

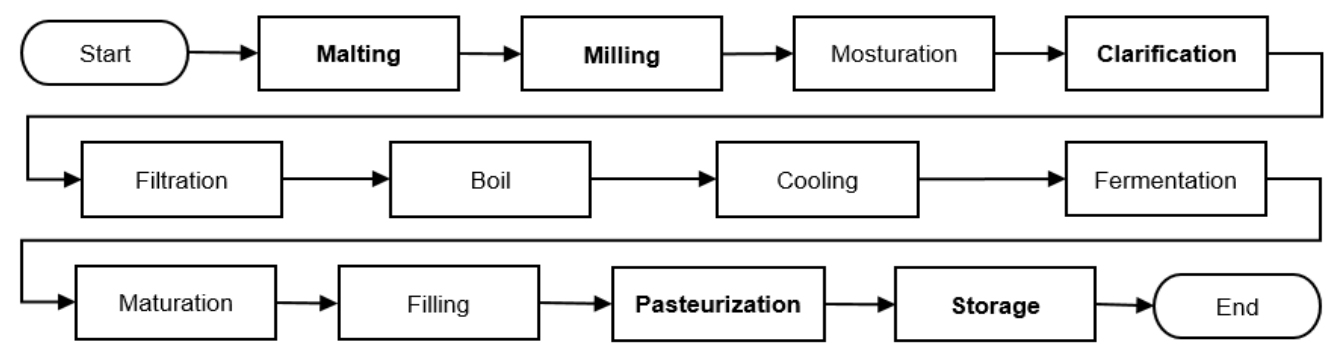

Source: Authors, 2020.

\subsection{Scenario Modeling and Simulation}

Firstly, the modeling and simulation of the unit process of an established batch was carried out. The batch obeys the recipe of the processes presented in item 3.1 of this work referring to table 1. The simulation via Petri net of the first scenario (Figure 4a) included two time measures focused on the fermentation activity at a controlled temperature of $9{ }^{\circ} \mathrm{C}$ and $18{ }^{\circ} \mathrm{C}$, maturation and storage in a dark place at room temperature. As they are not units of fixed measures, two distribution functions were proposed to perform the analysis of the results, namely: the first function proposed was exponential, where the time associated both for the transition from fermentation to $9{ }^{\circ} \mathrm{C}$ and $18{ }^{\circ} \mathrm{C}$ whose assigned time was a stochastic average of 7,200 minutes 


\section{$3^{\text {rd }}$ International Conference on Research in SCIENCE, ENGINEERING AND TECHNOLOGY}

\section{Ycoset}

11-13 March, 2021

\section{Oxford - United Kingdom}

followed an exponential distribution, in the same way it was also done with the maturation and storage processes. The same process was subjected to a uniform distribution, with an upper/lower limit of $10 \%$ on the stochastic average.

Figure 4: Modeling For Simulating The Experimental Process:
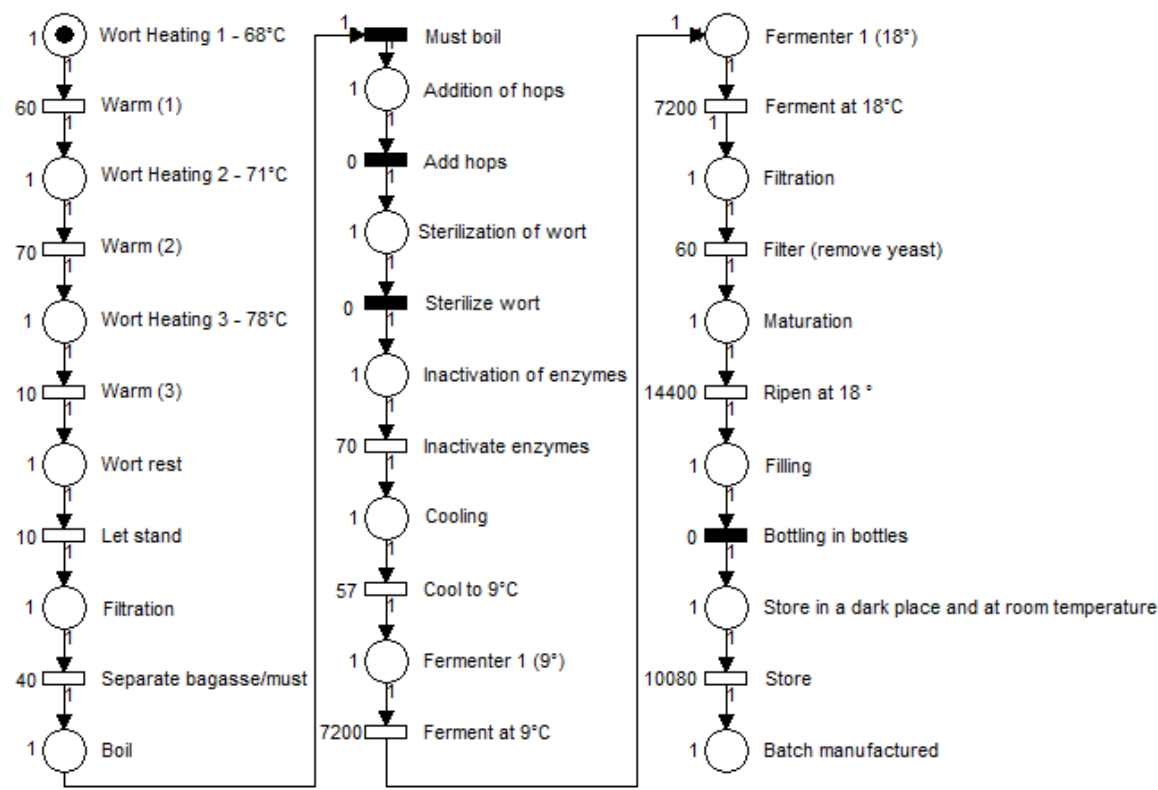

$a-$ Normal Process

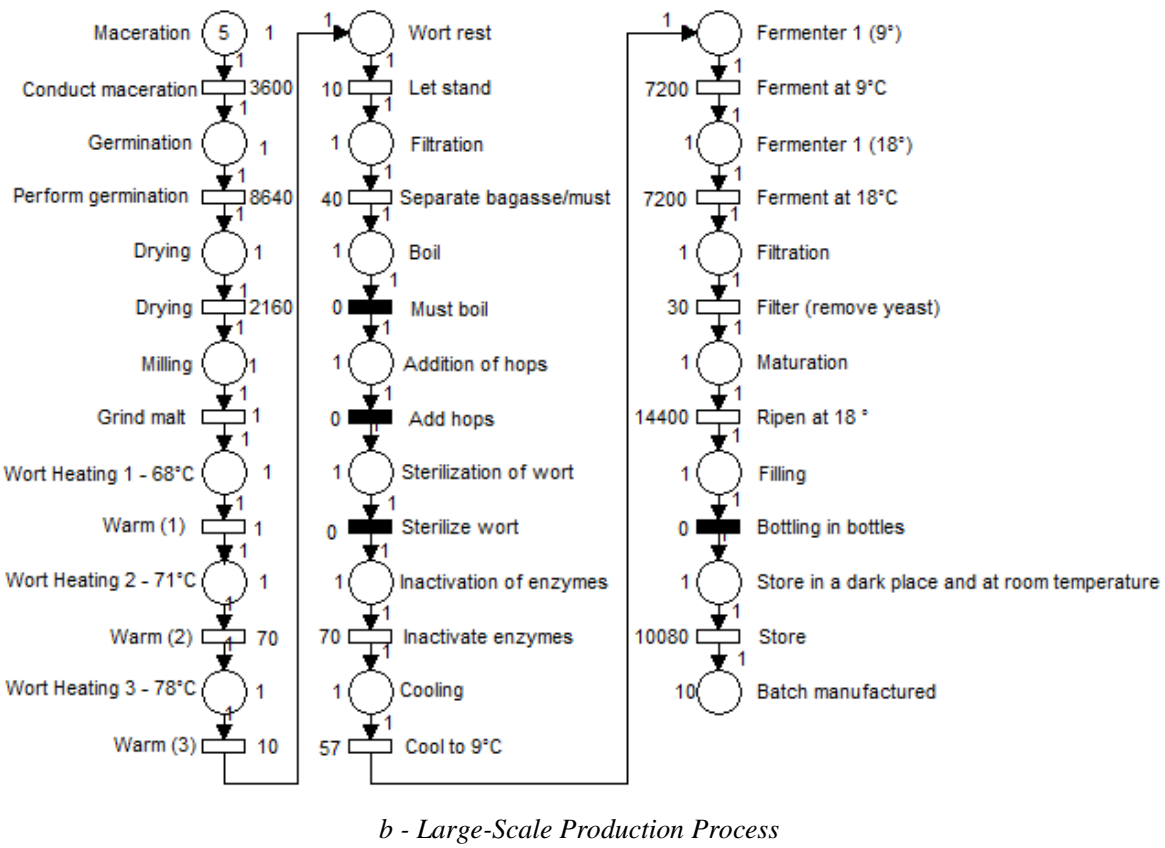

Source: Authors, 2020.

These scenarios were proposed to provide the manager with the ability to act on these processes, through statistical analysis (exponential distribution) or through a minimum and 


\section{$3^{\text {rd }}$ International Conference on Research in SCIENCE, ENGINEERING AND TECHNOLOGY}

11-13 March, 2021

\section{Oxford - United Kingdom}

maximum limit in order to meet a type of demand (uniform distribution). The results of this first experiment, as can be seen in the graphs of figure 5 and 6 , presented bottlenecks in the process, essentially in the processes listed previously, that is, fermenter 1 , both at $9{ }^{\circ} \mathrm{C}$ and 18 ${ }^{\circ} \mathrm{C}$, the process maturation and storage. Based on the analysis of the graphs represented in figure 5 of exponential distribution, table 3 was created. In this table, it is possible to observe that the four processes that the graphs demonstrated represent the bottlenecks of the total process which represent $99.00 \%$ of the entire process.

Table 3: Analysis of the results of scenario 1 of modeling and simulation (Exponential Distribution)

\begin{tabular}{|c|c|c|c|c|}
\hline Process & Starting point & End pointl & Time $(\min )$ & $\%$ \\
\hline Fermenter $1\left(9^{\circ} \mathrm{C}\right)$ & 327 & 4,614 & 4,287 & $10.97 \%$ \\
\hline Fermenter $1\left(18^{\circ} \mathrm{C}\right)$ & 4,614 & 12,288 & 7,674 & $19.64 \%$ \\
\hline Maturation & 12,349 & 28,999 & 16,650 & $42.60 \%$ \\
\hline Storage & 29,000 & 39,081 & 10,081 & $25.79 \%$ \\
\hline
\end{tabular}

Source: Authors, 2020.

Figure 5: Exponential Distribution

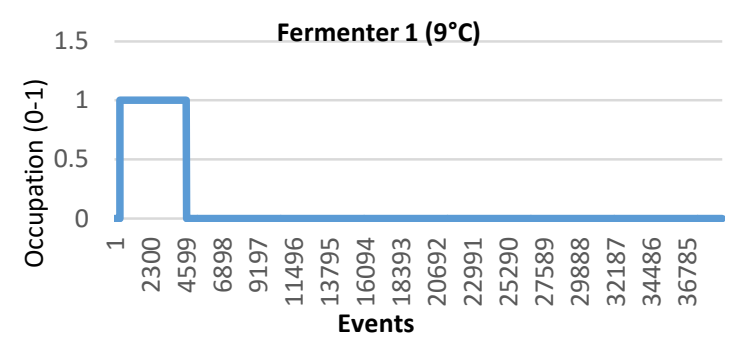

a) Evaluation 1

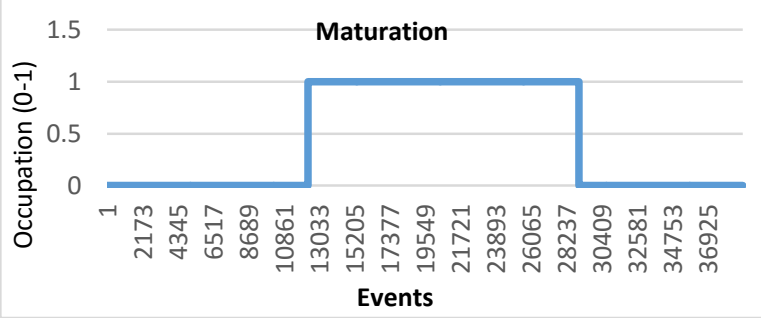

c) Evaluation 3

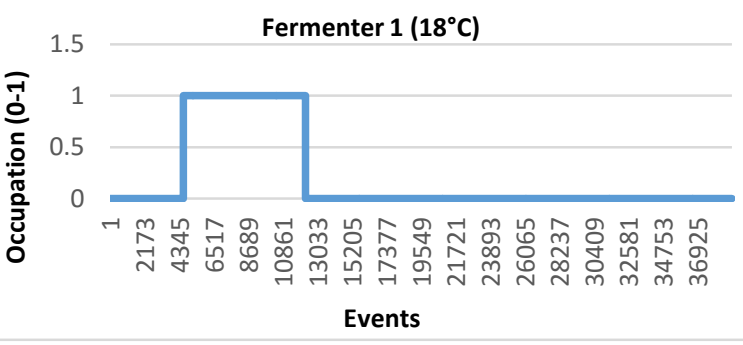

b) Evaluation 2

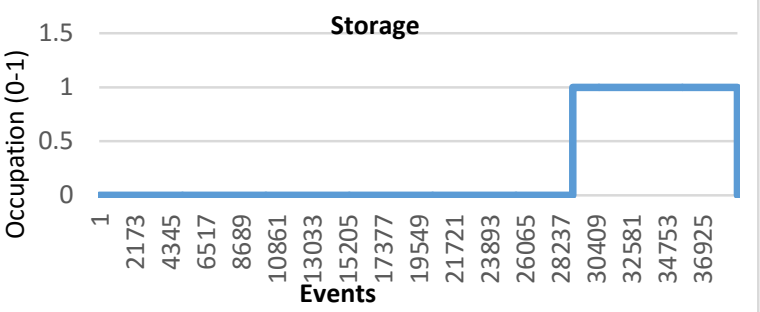

d) Evaluation 4

Source: Authors, 2020.

As it is an exponential distribution function, a fixed time is not used, so it was noticed that there is a possibility of time decreasing according to the variable. If a process automation occurs, the process may become more stable. The results achieved by the uniform distribution as can be seen in table 4, based on the analysis of the graphs referring to figure 6 , were not very different in relation to the results achieved in table 3 . 


\section{$3^{\text {rd }}$ International Conference on Research in SCIENCE, ENGINEERING AND TECHNOLOGY}

11-13 March, 2021

Oxford - United Kingdom

Table 4: Analysis of the results of scenario 1 of modeling and simulation (Uniform Distribution)

\begin{tabular}{|c|c|c|c|c|}
\hline Process & Starting point & End pointl & Time (min) & $\%$ \\
\hline Fermenter $1\left(9^{\circ} \mathrm{C}\right)$ & 327 & 8030 & 7,703 & $19.63 \%$ \\
\hline Fermenter $1\left(18^{\circ} \mathrm{C}\right)$ & 8,030 & 14,580 & 6,550 & $16.69 \%$ \\
\hline Maturation' & 14,641 & 29,556 & 14,915 & $38.00 \%$ \\
\hline Storage & 29,557 & 39,248 & 9,691 & $24.69 \%$ \\
\hline & & Total & 38,859 & $99.01 \%$ \\
\hline
\end{tabular}

Source: Authors, 2020.

It was possible to verify that the time and, consequently, the percentages were different, however, the final results showed very close values. Once the bottlenecks in the production process were determined, the simulation model was changed to scenario 2 , where the data that were collected for large-scale production (figure $4 \mathrm{~b}$ ), according to table 2 , were added to the model. For the analysis of the results, a batch of 100 liters of beer was considered for production. With the inclusion of the new processes, only one of the processes represented a bottleneck, as can be seen in table 5. Although the percentage of processes with bottlenecks has decreased from $99.01 \%$ in scenario 1 to $92.03 \%$ in scenario 2, the inclusion of processes increased the total time of the production process, resulting in 50,608 minutes (35 days, 3 hours and 28 minutes) considering an exponential distribution.

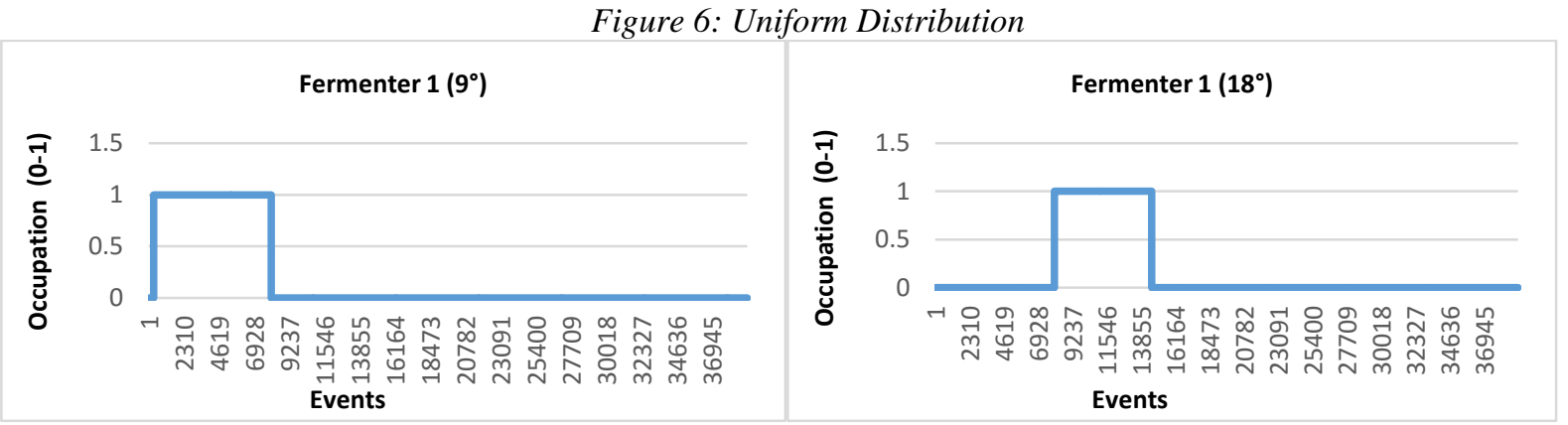

a) Evaluation 1

b) Evaluation 2

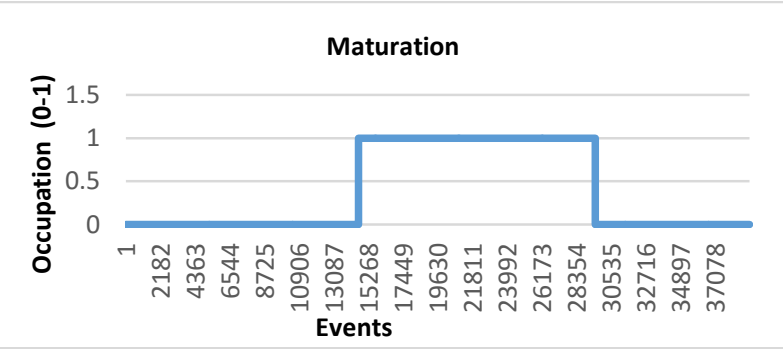

c) Evaluation 3

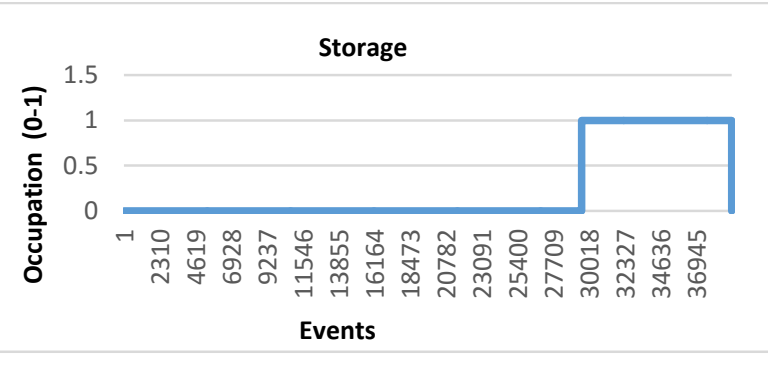

d) Evaluation 4

When simulating scenario 2 by means of a uniform distribution, it was possible to verify that the percentage of processes with bottleneck is lower in relation to scenario 1 with exponential distribution, which went from $92.03 \%$ to $87.69 \%$. However the total time of the process simulation was the highest value presented in the results of all the analyzed scenarios, which resulted in 54,031 minutes (37 days, 12 hours and 31 minutes). The two scenarios presented in tables 5 and 6 , present the processes that have bottlenecks in the total process of manufacturing gluten-free craft beer. It was verified that the simulations of the production process for a batch 


\section{$3^{\text {rd }}$ International Conference on Research in SCIENCE, ENGINEERING AND TECHNOLOGY}

\section{Oxford - United Kingdom}

of 100 liters of beer resulted in the following total times, considering the two types of distribution, namely: exponential distribution and uniform distribution, respectively 50,608 minutes ( 35 days, 3 hours and 28 minutes ) and 54,031 minutes (37 days, 12 hours and 31 minutes). Simulation of scenarios was carried out to demonstrate and analyze bottlenecks during the process, to assess the concentration points of activities.

Modeling and simulation were performed using 10 and 20 lots, in an exponential distribution (Figure 7). According to data in figure 8, it is possible to obtain the percentage of concentration of the processes that have bottlenecks and which equipment has greater use. It can be concluded that when production doubles, consequently an increase in the percentage of use happens. For the simulation using scenarios of 10 and 20 lots, 4 equipment were used in the stages that present bottlenecks, these equipment worked in parallel. According to figure $8 \mathrm{a}$, in the germination process, in the scenario of 10 lots, germinator 3 presented the highest utilization rate in the simulation process. In the scenario of 20 lots, germinator 4 presented a higher utilization rate. Other observations made were that in both scenarios, germinator 3 presented a close utilization rate, germinator 2 , in the 10 batch scenario, presented half the utilization rate of the 20 batch scenario. According to figures $8 \mathrm{~b}$ and $8 \mathrm{c}$, fermenter 1 , both for fermentation at $9{ }^{\circ} \mathrm{C}$ and for fermentation at $18{ }^{\circ} \mathrm{C}$, presented a higher percentage regarding the utilization rate in the scenarios of 10 and 20 batches.

Table 5: Análise dos resultados do cenário 2 da modelagem e simulação (Distribuição Exponencial)

\begin{tabular}{|c|c|c|c|c|}
\hline Process & Starting point & End pointl & Time (min) & $\%$ \\
\hline Germination & 2,144 & 11,351 & 9,207 & $18.19 \%$ \\
\hline Fermenter $1\left(9^{\circ} \mathrm{C}\right)$ & 13,205 & 21,045 & 7,840 & $15.49 \%$ \\
\hline Fermenter $1\left(18^{\circ} \mathrm{C}\right)$ & 21,045 & 28,102 & 7,057 & $13.94 \%$ \\
\hline Maturation & 28,133 & 40,524 & 12,391 & $24.48 \%$ \\
\hline Storage & 40,526 & 50,606 & 10,080 & $19.92 \%$ \\
\hline & & Total & 46,575 & $92.03 \%$ \\
\hline
\end{tabular}

Source: Authors, 2020.

Table 6: Analysis of the results of scenario 2 of modeling and simulation (Uniform Distribution)

\begin{tabular}{|l|l|l|l|l|}
\hline Process & Starting point & End pointl & Time $(\mathrm{min})$ & $\%$ \\
\hline Germination & 3,953 & 12,476 & 8,523 & $15.77 \%$ \\
\hline Fermenter $1\left(9^{\circ} \mathrm{C}\right)$ & 15,109 & 22,812 & 7,703 & $14.26 \%$ \\
\hline Fermenter $1\left(18^{\circ} \mathrm{C}\right)$ & 22,812 & 29,362 & 6,550 & $12.12 \%$ \\
\hline Maturation & 29,423 & 44,337 & 14,914 & $27.60 \%$ \\
\hline Storage & 44,339 & 54,029 & 9,690 & $17.93 \%$ \\
\hline & & Total & 47,380 & $87.69 \%$ \\
\hline
\end{tabular}

Source: Authors, 2020. 


\section{$3^{\text {rd }}$ International Conference on Research in SCIENCE, ENGINEERING AND TECHNOLOGY}

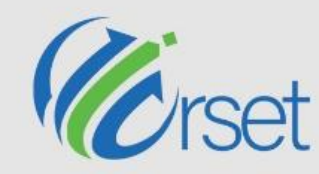

11-13 March, 2021

Oxford - United Kingdom

Figure 7: Modeling for Simulation for Scenarios Of 10 And 20 Production Lots
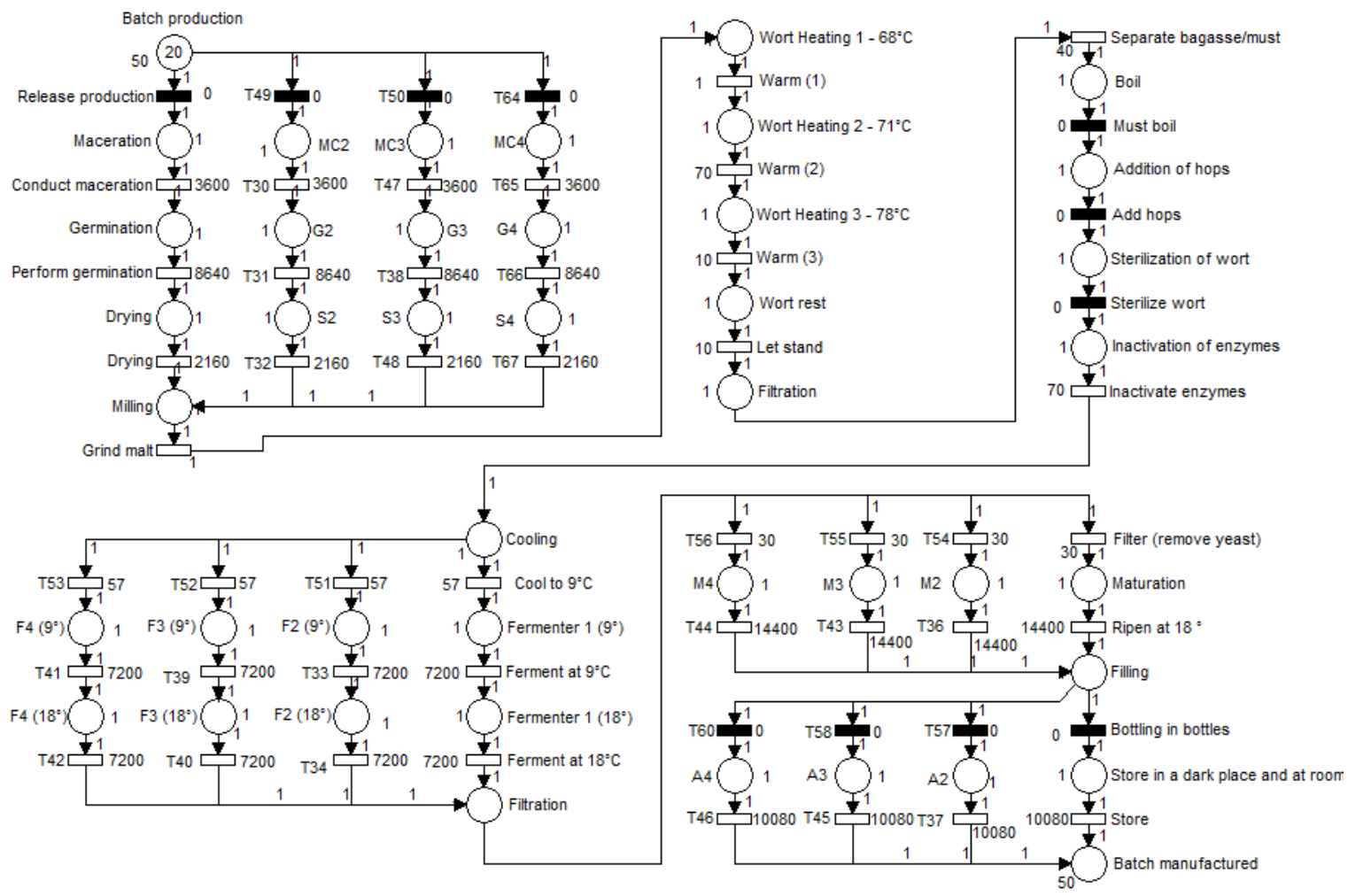

Source: Authors, 2020.

It was possible to observe that in the scenario of 20 batches in the fermentation process at $9^{\circ} \mathrm{C}$, the utilization rates of the fermenters were approximate, and in the fermenters of the $18{ }^{\circ} \mathrm{C}$ process a significant increase in utilization rates was also observed. This can be explained by the generation of queues in these processes, which demanded the greater use of equipment in the simulation of scenarios. At maturation, as shown in figure 8d, the equipment showed similar behaviors, with values of similar utilization rates. Except maturer 2 presented a $21 \%$ utilization rate in the scenario of 10 lots, representing $10 \%$ less than the average and maturer 4 presented $33 \%$ in the scenario of 20 lots, this value being $9 \%$ below the average. In the storage process, the utilization rate was higher in storage 3 in the 10 batch scenario and in storage 2 and 4 in the 20 batch production scenario. In addition, the processes showed equal values in both scenarios, in storage 2 and 4 , as shown in figure 9. 
Figure 8: Concentrations (Exponential Distribution)

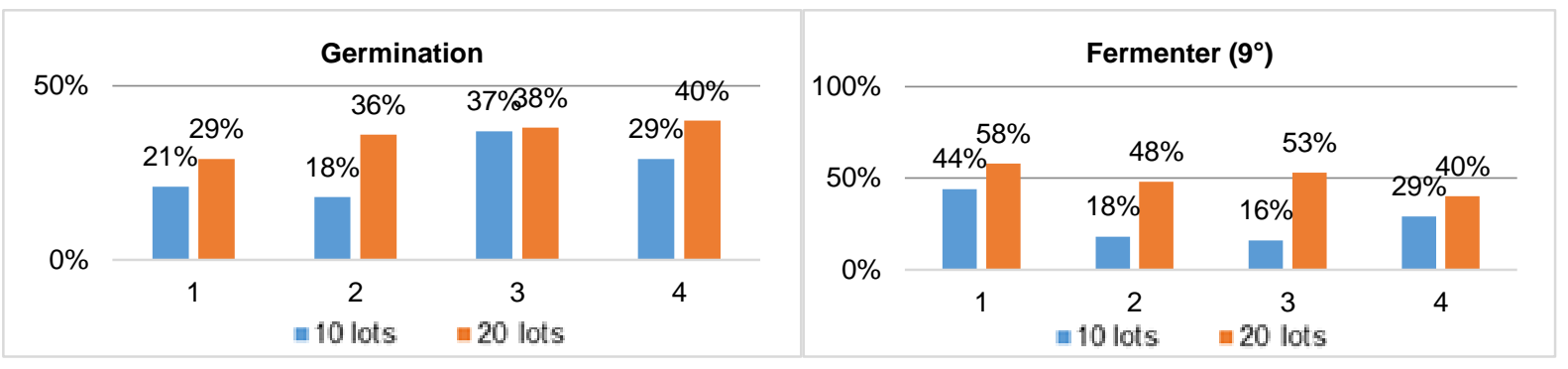

a) Evaluation 1

b) Evaluation 2

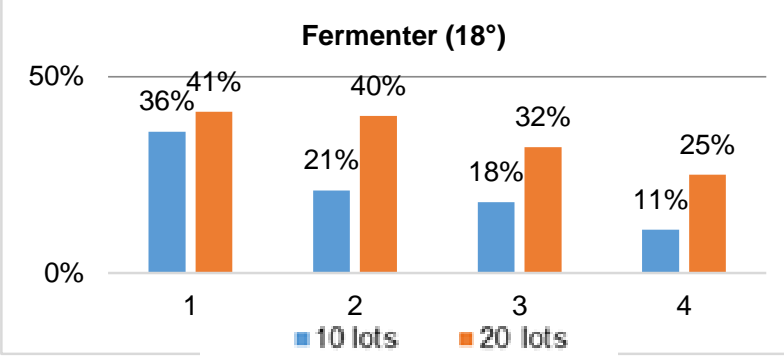

c) Evaluation 3

Source: Authors, 2020.

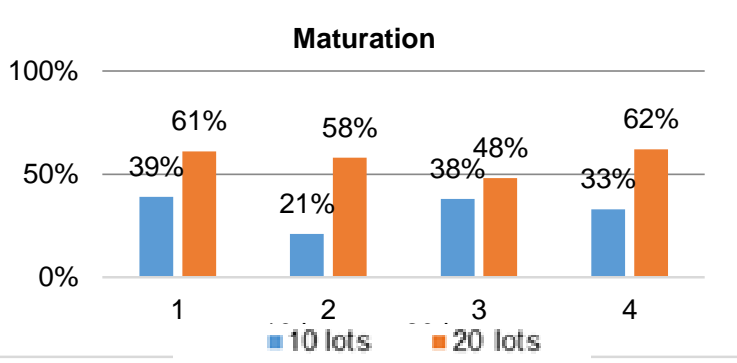

d) Evaluation 4

Figure 9: Concentration in Storage (Exponential Distribution)

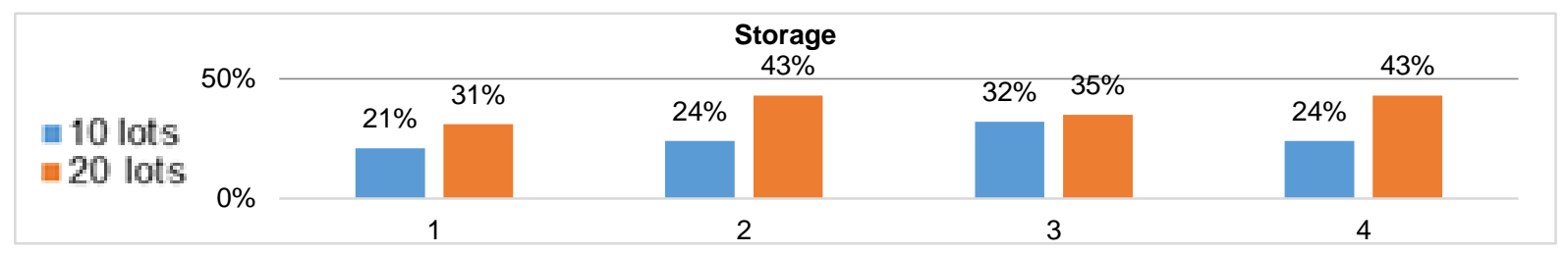

Source: Authors, 2020.

During the simulation it was possible to observe that there are bottlenecks, as the batches have to wait for availability to start the later stages. Such simulations can show that in real processes, differences in the utilization rate of equipment in processes must be analyzed, since equipment with higher utilization rates may generate the need for maintenance, in addition to increasing the risk of wear. The process was analyzed and through simulation, it was possible to know with the purchase of equipment and revalidation of times, how the process can flow for specific lots. Therefore, it is possible to optimize the purchase process.

\section{Conclusion}

The objective of this work was to develop a methodology based on modeling and simulation of scenarios for the production of gluten-free beer for a micro and small entrepreneur. The flowchart of the production process was developed, based on its activities, times and resources. Thus, it was possible to measure the time required for the production of production processes, which resulted in 27 days, 6 hours and 17 minutes for the experimental process model and 37 days, 6 hours and 17 minutes for the large-scale process. 


\section{$3^{\text {rd }}$ International Conference on Research in SCIENCE, ENGINEERING AND TECHNOLOGY}

Based on the activities of the production processes, it was possible to develop the modeling and simulation of the process through the Petri net. Scenarios with exponential distribution and uniform distribution were simulated for the purpose of comparing results. The results showed that the experimental production had bottlenecks in the fermentation, maturation and storage processes, such bottlenecks represented $99.00 \%$ of the entire production process in the simulation with exponential distribution and $99.01 \%$ with uniform distribution. For the largescale production process model, the results showed the same bottlenecks, but with the addition of the germination process, where the bottlenecks presented, for exponential and uniform distribution, respectively, $92.03 \%$ and $87.69 \%$ of all the production process.

Finally, simulations were carried out with simulation scenarios of 10 lots and 20 lots of beer. The results showed the utilization rates of each production unit within the production process. These statistical data are essential for the micro and small entrepreneur to monitor the production process and to monitor the maintenance and status of the equipment involved in the process. Future work can be carried out based on the current, such as the survey for the acquisition of the necessary equipment for production based on the activities, times and resources presented and based on simulation scenarios that can be observed. 


\section{References}

[1] Serviço Brasileiro De Apoio Às Micro E Pequenas Empresas - SEBRAE (2018). Pequenos negócios em números. São Paulo. Available in http://www.sebrae.com.br/ . Access in: 29 Apr. 2020.

[2] Associação Brasileira Da Indústria De Cerveja - CERVBRASIL (2018). Dados do setor cervejeiro nacional. São Paulo: CERVBRASIL. Available in http://www.cervbrasil.org.br/novo_site/anuarios/CervBrasil-Anuario2016_WEB.pdf Access in: 31 Apr. 2020.

[3] Ferreira, R. H., Vasconcelos, M. C. R. L., Judice, V. M. M. and Neves, J. T. D. R. (2011). Inovação na fabricação de cervejas especiais na região de Belo Horizonte. Perspectivas em Ciência da Informação, 16(4), 171-191.

[4] Arendt, E. and Dal Bello, F. (Eds.). (2011). Gluten-free cereal products and beverages. Elsevier.

[5] Walter, H. L. and Meluch, A. L. (2019). Measurement in Organizational Communication. Communication Research Measures III: A Sourcebook.

[6] Stocker, F.; Abib, G. (2019) Gerenciamento de Riscos em Born globals: o caso das Cervejarias Artesanais Brasileiras. BBR. Brazilian Business Review, v. 16, n. 4, p. 334349. http://dx.doi.org/10.15728/bbr.2019.16.4.2 .

[7] Associação Brasileira De Cerveja Artesanal - ABRACERVA (2018). Número de cervejarias artesanais no Brasil já cresceu 23\% em 2018. Cidade: ABRACERVA. Available in: https://abracerva.com.br/2018/10/04/numero-de-cervejarias-artesanais-no-brasil-jacresceu-23-em-2018/ . Acesso em: 20 Jan. 2020.

[8] Lisboa, A. C., De Souza, F. H. B., Ribeiro, C. M., Maia, C. A., Saldanha, R. R., Castro, F. L. and Vieira, D. A. (2019). On modelling and simulating Open Pit mine through stochastic timed Petri nets. IEEE Access, 7, 112821-112835. 